\title{
Intelligent Design of Inclusive Growth Strategies
}

\section{Citation}

Kaplan, Robert S., George Serafeim, and Eduardo Tugendhat. "Intelligent Design of Inclusive Growth Strategies." Harvard Business School Working Paper, No. 20-050, October 2019.

\section{Permanent link}

http://nrs.harvard.edu/urn-3:HUL.InstRepos:41711870

\section{Terms of Use}

This article was downloaded from Harvard University's DASH repository, and is made available under the terms and conditions applicable to Other Posted Material, as set forth at http:// nrs.harvard.edu/urn-3:HUL.InstRepos:dash.current.terms-of-use\#LAA

\section{Share Your Story}

The Harvard community has made this article openly available.

Please share how this access benefits you. Submit a story.

Accessibility 


\section{Intelligent Design of Inclusive Growth Strategies}

Robert S. Kaplan

George Serafeim

Eduardo Tugendhat

Working Paper 20-050 


\title{
Intelligent Design of Inclusive Growth Strategies
}

\author{
Robert S. Kaplan
}

Harvard Business School

George Serafeim

Harvard Business School

Eduardo Tugendhat

The Palladium Group

Working Paper 20-050

Copyright (C 2019 by Robert S. Kaplan, George Serafeim, and Eduardo Tugendhat.

Working papers are in draft form. This working paper is distributed for purposes of comment and discussion only. It may not be reproduced without permission of the copyright holder. Copies of working papers are available from the author.

Funding for this research was provided in part by Harvard Business School. 


\section{"Intelligent Design of Inclusive Growth Strategies"}

October 2019

\section{Robert S. Kaplan}

rkaplan@hbs.edu

Senior Fellow and Marvin Bower Professor of Leadership Development, Emeritus Harvard Business School

Soldiers Field

Boston MA 02163

(O) (617) 495-6150

(M) (617) 407-7194

George Serafeim

gserafeim@hbs.edu

Charles M. Williams Professor of Business Administration

Harvard Business School

Soldiers Field

Boston MA 02163

(O) (617) 495-6548

Eduardo Tugendhat,

Eduardo.Tugendhat@thepalladiumgroup.com

Director, Thought Leadership

The Palladium Group

1331 Pennsylvania Ave., NW

Suite 600, Washington, DC 20004

(O) (202) 775-9680 


\title{
"Intelligent Design of Inclusive Growth Strategies"
}

Robert S. Kaplan, George Serafeim, Eduardo Tugendhat

\begin{abstract}
Improving corporate engagement with society, as advocated in the Business Roundtable's 2019 statement, should not be viewed as a zero-sum proposition where attention to new stakeholders detracts from delivering shareholder value. Corporate programs for sustainable and ethical sourcing practices, however, have fallen far short of solving the underlying causes of extreme poverty, extensive use of child labor, and threats to the environment and human health. We identify several causes to explain this disappointing shortfall in societal performance, including traditional company policies and incentives that inhibit the implementation of innovative, inclusive growth strategies. We propose the role for a new actor, a catalyst, to help companies forge new relationships with external funders, local intermediary companies, NGOs, and community leaders. The catalyst aligns the multiple stakeholders from multiple sectors into enduring, mutually- beneficial relationships that produce more value than that currently produced when stakeholders connect only by transactional relationships. The catalyst attracts funding from public and private sources to invest in the new ecosystem, which can generate attractive financial returns while alleviating poverty and environmental degradation. Finally, the catalyst engages the multiple participants to collectively co-create explicit strategies and scorecards of metrics, which serve to motivate, create accountability, and enable an enduring governance model for a multistakeholder ecosystem.
\end{abstract}




\section{"Intelligent Design of Inclusive Growth Strategies"}

The Business Roundtable's 2019 updated Statement on the Purpose of a Corporation explicitly added a commitment to work fairly and ethically with suppliers, support the communities in which we work, and protect the environments by embracing sustainable practices. Many global companies, especially those in agribusiness, have already embraced sustainable and ethical sourcing practices with their suppliers, that could, in principle, reach many of the seven hundred millions of smallholder farmers still living in dire poverty. The companies' enthusiasm for the new practices was often stimulated by unfavorable publicity about social and environmental problems somewhere in their supply chains, such as destruction of tropical forests, workers injured or killed, or use of child labor on farms and factories. The adopting companies announced targets, often $100 \%$, for sustainable sourcing along with intentions to become certified as compliant while also addressing underlying causes for noncompliance, such as farmer poverty. They dedicated major resources to farmer training and community support programs, mostly implemented by NGOs. Estimates suggest that companies and donor organizations spent, just for cocoa purchasing, more than $\$ 1$ billion in sustainability programs. Retailers and brands of apparel and footwear added minimum labor standards to their compliance certification programs and established programs to improve worker skills and conditions.

Certification initiatives can, in principle, deliver the desired results and be sustained if one or more of the participants in the value chain willingly pays a premium for certified products. Alternatively, they can be successful if certification is so important to many end-use consumers that companies cannot compete without it. Neither of these situations, however, has occurred yet in practice. The wellmeaning corporate efforts have faltered because of the harsh economic reality that procurement of commodity products is driven more by price and quantity than by the quality and sustainability of their production processes (see Appendix, "Sustainable and poverty-alleviating agricultural supply chains are elusive").

With consumers generally unwilling to be loyal to or pay premium prices for certified products, local aggregators and other intermediaries who link smallholder farmers to corporate markets had little financial incentive to make the costly investments to become compliant with new standards. This left tens of millions of impoverished small-scale farmers with uneducated and now unemployable children and with reduced access to global supply chains. Consider the pressure exerted by conservationists 
intended to force consumer brand companies to stop destroying rainforests for palm oil production. The companies, along with NGOs and governments, organized the Roundtable on Sustainable Palm Oil (RSPO) and committed to buying only RSPO certified oil. The certification program reached large plantation and oil extractors but had little impact on the estimated 3 million smallholder farmers who also grew oil palm. These farmers, with no financial benefits from sustainable production accruing to them, continued to plant new trees on land created by slashing and burning rainforests.

Beyond the lack of incentives at the smallholder farmer and village aggregator level, many companies further up the value chain, including the final off-take corporation, had few customers that cared deeply about social and environmental issues. Additionally, the high error rates in the monitoring technology used to certify the growing and processing of agricultural commodities led to significant noncompliance throughout the supply chain. Many product certification efforts reached an upper limit of $25 \%$ of global production and then leveled off, leaving a bifurcated market: a certified portion with its own standards and market dynamics, and a large uncertified market with millions of impoverished smallholder famers. Corporate sustainability programs, while noble in intent, have fallen far short of solving the underlying causes of extreme poverty, extensive use of child labor, and local threats to the environment and human health.

A further dynamic occurred as certified Tier 1 (direct) and Tier 2 (indirect) suppliers could not further increase the productivity of their existing suppliers without major new investment. For example, even as worldwide demand for food increased, and concerns heightened about climate, water, and land-use, farmers were willing to invest in environmentally sustainable practices only if they could be confident that payments to them would be less volatile and also higher to cover their incremental costs for instituting such practices. Agribusiness companies, if they are to breakthroughs such rational resistance for sustainability, must create entirely new system-wide sustainability strategies and new approaches for implementing them.

\section{A brief history of corporate sustainability programs}

Companies' traditional sustainability programs have evolved over time (Rangan, Chase, and Karim,2015). Initially, companies improved local social conditions by creating a corporate foundation or philanthropy office to distribute funds to community, educational, and health organizations. Subsequently, they established corporate social responsibility (CSR) and compliance offices, typically after publicized 
violations of governmental regulations or unacceptable business practices, such as bribery, corruption, environmental pollution, deforestation, and unsafe or unhealthy working conditions. Corporate staff groups strived to eliminate companies' negative impacts on society and reduce their reputational risks by expanding their compliance programs, meeting community expectations for safe and fair employment practices, and becoming certified for sustainable sourcing. The metrics currently used for sustainability reporting and monitoring focus on demonstrating that companies do no harm: trees are not cut down, workers are not injured, child labor is not used, and emissions of greenhouse gases are not increasing. These metrics, however, have no information on whether the socio-economic status of local populations has improved. Most food and apparel compliance, certification and sustainability programs serve, essentially, as risk mitigation initiatives.

More recently, companies have implemented operational excellence programs to reduce inefficiency and waste, and improve workplace health and safety. These programs, often referred to as shared value strategies, save money for the company while also demonstrating its good corporate citizenship as a cleaner, safer, healthier and more enlightened employer. For example, major beverage companies such as InBev, Coca-Cola and Pepsi have introduced large-scale initiatives to improve water stewardship and recyclable packaging. The programs both lower costs for the company and deliver modest benefits for the environment. But as with the compliance measures, the operational excellence programs demonstrate good deeds by the company, but not improvements in the economic status, health, and employment of local populations.

Companies should continue to be philanthropic, comply with regulations and societal expectation, and operate efficiently to reduce waste and employee hazards. All these efforts deliver incremental societal benefits. But to "move the needle" on severe poverty, inequality and environmental degradation, companies need to embed new programs within a compelling business case, called inclusive growth strategies.

After studying dozens of sustainability programs, we have found several limitations in the traditional approaches that corporations have used to deliver societal benefits:

1. They use corporate discretionary funds to support CSR and sustainability programs, rather than treat the programs as investments to be repaid by future financial returns.

2. They fail to link sustainability and CSR initiatives to measurable outcomes important to residents in low-income communities and other entities in their supply chains, and to society, in general. 
3. They don't attract external financing to invest in systemic solutions that generate returns to multiple stakeholders.

4. They lack internal capabilities to design and execute strategies that require alignment and integration among numerous external entities.

Companies can overcome these challenges, but they must change their business-as-usual policies and incentives that currently inhibit the implementation of innovative, inclusive growth strategies. Companies must forge new relationships with entities outside their immediate control, such as external funders, local intermediary companies, NGOs, and community leaders. Such integrated, multi-actor solutions make supply chains more efficient and effective, open profitable new market opportunities for the participating companies, and provide a pathway to better jobs, income, and consumption for previously impoverished local residents. If these tasks were easy to do, however, they would have occurred already. A new actor, which we call the catalyst, needs to be introduced to help the corporation design and implement inclusive growth ecosystems.

\section{The Catalyst}

The role of the catalyst is to gather and align the multiple stakeholders required for enduring, mutuallybeneficial relationships that produce more value than that currently produced when the stakeholders connect only by short-term transactional relationships. A catalyst should be more familiar with the local and regional opportunities than a company's sustainability officer, based at corporate headquarters. The catalyst should be trusted by the players from each sector to produce approaches and an implementation plan that is fair to all and biased to none. In particular, the catalyst must understand and value that for-profit entities, typically the corporate participants, must earn and a good return on their investment of money and people into the ecosystem. The catalyst must ensure that residents of local communities realize demonstrable and significant improvements in key socio-economic indicators such as net income, family diet, and children's education. The catalyst should also facilitate the mobilization of capital, from multiple funding sources, to finance the establishment of the ecosystem and its initial growth trajectory.

We have seen different kinds of catalysts implement successfully in practice. Some companies, such as Syngenta, now use an internal catalyst after its initial attempts to implement its Good Growth sustainability program increased neither the profits of its core crop protection businesses nor the incomes of local farmers. In a new facilitating role, the team convened groups of farmers, customers, 
other suppliers, and intermediaries, as well as its own commercial and R\&D teams, to hear the perspectives of each actor and to learn how to work on new products with a collaborative business model.

A second type of catalyst involves progressive intermediaries or enterprises that help link end-buyers and producers with long term supply relationships. Joven 360 , for example, helps to bring together youth, companies, and other entities into a workforce ecosystem in five Central and South American countries. Kennemer Foods links cocoa and banana famers to financing, service providers, and endpurchasers in the Philippines.

A third type of catalyst involves development vehicles, supported by anchor companies as strategic partners, that structure, operate and scale inclusive growth solutions. For example, Kaiser Permanente, after learning of the large impact of social determinants on health, established a fund, with external investors and real estate developers, to finance affordable housing in Oakland and other cities. Kaiser required its contractor to reserve 30 percent of all jobs for people living within five miles of the site, and spend $\$ 24$ million of the $\$ 90$ million construction costs with women- and minority-owned businesses.

The fourth type of catalyst is an innovator from the public or nonprofit sector. Golden Triangle Development LINK, a regional development agency in northeast Mississippi, acted as the catalyst for public-private partnerships among the state, TVA (electrification), local universities, and a financing authority to attract companies that have built and now operate manufacturing plants and pay high wages to formerly-unemployed workers in the region (Fuller et al, 2018). Any of these types of catalysts can be supported by external consultants playing an "honest broker" role that helps the different actors to come together to create a shared vision, design an inclusive growth strategy, and then execute on that strategy.

In the remainder of the paper, we describe how the catalyst supports each of the stages required to design, build, and sustain a successful inclusive growth ecosystem.

\section{Develop Inclusive Growth Strategies}

Companies and their catalysts should start the search for an inclusive growth strategy by identifying the current gaps that isolate low-income, marginalized people from the regional and global supply chains for 
goods, services, and talent (see Kaplan, Serafeim, and Tugendhat (2018)). Since most companies lack visibility into the economics of their supply chains any deeper than their Tier 1 suppliers, the catalyst helps them assess and map the current set of relationships, feedback loops, and economic incentives among all the existing and potential players in regional supply chains ( See Exhibit 1, "Cacao Supply Chain"). The map helps companies identify existing Inefficiencies and perverse incentives, typically caused by short-term, informal and fragmented relationships among many of the players. For example, the company may be procuring goods based on the spot market prices of goods or distributing its goods and services through small, inefficient, poorly financed, and untrained intermediaries. Gaps also arise from the distrust in communities of top-down corporate-led initiatives; for examples, when local residents continue to steal from or sabotage electrical distribution lines and gas pipelines even after the utility company has explained the benefit from sustainable and reliable supply of energy to their homes.

Once the company understands the existing inefficient ecosystem, the catalyst helps it re-imagine and intelligently design a new business approach to integrate marginalized communities into a global supply chain. The re-design is not just tweaking the existing system to make it a little better, faster, and cheaper. It requires fundamental changes in local incentives and relationships, and recruitment of new players and resources that have the potential to create order of magnitude improvements, especially for the residents in the engaged communities of the redesigned ecosystem. The catalyst, with the company operating as the "anchor partner," identifies and helps to recruit key players currently missing from the system but who must be present to release the potential value from having all the actors, including new investors, collaborate in a new inclusive growth strategy.

An inclusive growth strategy must be economically attractive and self-sustaining for the company. This enables funding to shift from discretionary grants from the sustainability office to the investment companies willingly make to generate future cash flows from a profitable business. An internal challenge arises, however, from the short-term horizon under which most business units operate, especially those procuring or distributing products and services in low income countries. Corporate finance officers monitor closely and frequently a business unit's sales, costs, and profits. Inclusive growth strategies, however, require extended time periods to build a new ecosystem of multi-sector relationships, and for these systems to deliver on their targeted performance. A new agribusiness supply chain takes several years before enough farmers and aggregators participate in it to deliver increased production of high quality, sustainably grown products to a corporate end-user. Business units held accountable for 
quarter-by-quarter increases in profits can find it difficult to make the required multi-year investment for such a strategy. This is not an unsolvable problem. Obviously, the business unit's financial targets can be adjusted to reflect the longer payback period from inclusive growth strategies. More powerfully, the company can shift the accountability of business units away from an exclusive reliance on short-term financial performance to a more robust balanced scorecard of both financial and non-financial metrics (more on this later in the paper). In these ways, local business unit leaders obtain the time and incentives to realize the return on their investment from an inclusive growth strategy.

Even when companies modify their internal measurement and incentive systems, they still may not be able to engage with various other entities that are required for the new business model to work. Business units must recognize that the success from an inclusive growth strategy is not determined solely by their actions. This runs counter to company incentive plans, operating under the "controllability principle," in which executives' bonus plans are based on performance under managers' control. That is why operational excellence programs are popular in sustainability programs. The rapid improvement in costs from eliminating waste and inefficiencies is both predictable and controllable by the business unit leader.

Inclusive growth ecosystems, however, require a local business unit leader to be only one player among many, with the overall performance of the system dependent on how well all other ecosystem participants embrace and execute their roles. The assessment of a business leader's performance must include the achievement of economic and environmental outcomes for others in the ecosystem, especially those in marginalized communities who participate as the system's suppliers, employees, and customers. This too is not an unsolvable problem. Simons (2005) has defined the entrepreneurial gap as the difference between the broad measures for which an executive is accountable relative to the narrow range of resources over which the executive has direct control. Executives bridge such entrepreneurial gaps by taking actions that influence the behavior and actions of those over whom they don't have direct control or authority. They can act in ways that earns trust for longer-term relationships with the business unit's suppliers, customers, and alliance partners. The catalyst helps in this trust and relationship-building exercise by coaching and demonstrating in practice, for all the participants, current and prospective, the system changes required for long-term partnering relationships. Nonprofits and public sector units must understand that corporate and investor participation in the ecosystem requires it to earn a satisfactory profit. In turn, the business unit leader must understand that participation by 
nonprofits and public enterprises requires demonstrable improvement in the lives of the previously marginalized residents in local communities. All players must understand their individual roles and the inter-relationships among them that are required for the collaboration to be successful, sustainable, and scalable.

\section{Finance the Inclusive Growth Ecosystem}

Accessing finance and getting it where and when it is needed in the ecosystem is one of the principal challenges for the catalyst. The catalyst can connect impact investors with companies wanting to serve either as the off-taker for locally produced products and services or the employer for trained local talent. In this way, the catalyst mitigates the current malfunction in the social capital market: impact investors have an excess of capital to deploy relative to the supply of projects that generate both financial and societal outcomes, while companies face capital shortages to fund the front-end investments to design and build a new, higher-valued regional supply chains for products and talent. Active engagement with corporations lowers external investors' risk in a variety of ways: the corporation can be the eventual customer (off-taker) for locally grown or produced products, the employer for recently-trained local talent, or the supplier of goods and services, specifically designed to be accessible to low-income and previously-marginalized local populations. The catalyst makes the market for social impact investments more efficient by bringing the available supply and latent demand for capital together.

Funders and the corporations must agree on the desired outcomes from the inclusive growth ecosystem, such as higher production and incomes for farmers, improved soil quality, and reduced deforestation. These outcomes must be designed into the financial contract with external investors. Such contingent contracts have become common in public-private partnerships, particularly those financed with social impact bonds. In these partnerships, the government pays a higher interest rate on the bond when specified outcomes, such as reduced rates of crime recidivism, are realized. Such outcomes-contingent financing has yet to be used, however, to link impact investors to regional supply chains. The catalyst can be the innovator by helping participants design and measure the outcomes that subsequently become embedded in the contract design between the capital suppliers and the local producers. 
Since, potentially, funding may come from a variety of sources - impact investors, foundations, public sector agencies, and the corporation itself - the catalyst can create a special purpose vehicle (SPV) for the investment. The SPV, with separate legal standing, receives the funds from external investors and, in return, issues a bond, perhaps nonrecourse, or some other financial instrument, to them. The SPV not only finances the up-front ecosystem investment, it also serves as the vehicle for additional financing as the ecosystem grows in scale. In this way, the SPV solves the problem encountered by many previous sustainability projects that terminated after the initial financing was exhausted. Their fatal flaw was they had not been designed to generate financial returns sufficient for both investors and the small and large businesses in the system to provide ongoing capital inflows. Several pre-competitive alliances, also formed to address important societal challenges, relied on member contributions rather than the free cash flows earned from a more efficient, re-designed supply chain. The alliances ceased after the initial member contributions were exhausted.

The catalyst, as an independent party, would deploy the money from the SPV to farmers, intermediaries, and the local suppliers and distributors in the regional market and work actively with the corporation and the local players to produce the desired improved in financial and social outcomes. The improved performance would fund the SPV, enabling it to pay off the legal claims on the financial instrument. The source of the cash to pay these claims would be a share of the total value created in the ecosystem. The corporate contribution would be funded from its productivity gains and higher sales from the enhanced supply chain, local intermediaries would contribute from their higher profits, and local governments would share some of the increased taxes collected based on the higher incomes and wages of residents and local intermediaries.

Clearly, for such a complex financing scheme to be successful, the catalyst must build a consensus among all participants about the potential magnitude of anticipated value creation and how this will be shared among all the entities. The catalyst also must also help the participants design the specific metrics and formulas to guide the distribution of that value increase back to the SPV as discussed in the next section.

\section{Align and Govern the Inclusive Growth Ecosystem}

Creating a new ecosystem for an inclusive growth strategy is not for the faint-hearted. Even in businessto-business relationships, where each party can readily measure success by increases in revenues and 
profits, most strategic alliances fall far short of delivering their planned performance. Creating alignment among the varied participants in an inclusive growth ecosystem introduces the additional challenges of the existing distrust and lack of familiarity among entities coming from different sectors - private, public, and nonprofit, and the new dimensions - especially social and environmental metrics - for measuring success.

Companies engaged in business-to-business partnerships have found they can enhance the odds for successful implementation by co-creating an explicit strategy for the partnership and agreeing on the measurements that each wants to achieve (Kaplan, Norton, and Rugelsjoen (2010)). The co-creation enables each company to express its objectives and to hear and learn what the other party wants to achieve from the relationship. They can then design a strategy that enables both parties to achieve their respective goals. The dialogue between representatives from the two companies typically requires several meetings at which each learns about the other's aspirations and goals through candid, respectful, and productive discussions. The dialogue builds trust and understanding across organizational lines that enables both groups to continue to work together and solve the inevitable problems and issues that arise during actual implementation.

Many companies, either when creating an alliance across organizational boundaries or when integrating and aligning two previously autonomous companies after a merger or acquisition, use the co-creation of a strategy map to focus the conversation. The strategy map provides a visual representation of the strategy's objectives across the four perspectives of a Balanced Scorecard (financial, customer, process, learning \& growth). The companies then select measures for each strategy map objective, creating a Balanced Scorecard of measures that make the strategy operational and accountable for both parties.

\section{Creating Inclusive Growth Strategy Maps and Scorecards}

The catalyst can apply this process to the newly designed inclusive growth ecosystem by working interactively with each entity's representatives to collectively co-create the strategy for the ecosystem. The process involves developing a strategy map for the ecosystem (see Exhibit $\mathbf{2}$ as an example of a simplified strategy map for a cocoa supply chain), and then translating the strategy map into the scorecard of measures to be used by the ecosystem. The strategy map captures the financial and nonfinancial objectives the ecosystem is designed to deliver, including explicit responsibility for local 
customers and suppliers. The top-level objectives, rather than being only financial, as in a for-profit company's strategy, will include societal and environmental objectives as well.

The financial objectives and metrics are the accountability of the ecosystem to the external funders' SPV, the upstream suppliers, and the anchor corporation's shareholders. The environmental and societal objectives are the accountability to the communities where the ecosystem operates, to the mission goals of the impact investors, and to the corporation's commitment to operate a sustainable value chain that creates social value in communities where it purchases and acquires talent. The co-creation of a strategy, strategy map, and Balanced Scorecard of outcomes and process metrics aligns the multiple players around shared business, social and environmental outcomes.

In the next step, the catalyst assists each player to construct its individual strategy map and scorecard for participation in the inclusive growth ecosystem. For example, the objectives on the strategy map for a local intermediary would include the financial returns from aggregating and processing production from smallholder farmers and then distributing and selling to a corporate purchaser (its customer). Among its process objectives would be assisting local smallholder farmers with education, training, and financing. The strategy map for smallholder farmers would include objectives for improved incomes, better education and nutrition, and more sustainable farming practices. Each objective in a player's strategy map would have 1-3 accompanying measures that quantify the benefits and serve to align the player's actions and decisions to the ecosystem.

In a final design step, the catalyst links the individual strategy maps together (see Exhibit 3) in suppliercustomer relationships. For example, the smallholder farmer's customer is the local aggregator who serves, in turn, as the supplier to a regional distributor or the offtake corporation. The customer of a corporation selling inputs to farmers, such as seeds, crop protection, fertilizer, equipment, or irrigation would be a local distributor whose customer, in turn, is the smallholder farmer. The linked strategy maps of all ecosystem participants provides the visual representation of their inter-connections and how each member's success both depends on and also contributes to the successful performance of all others. 


\section{Governing the Inclusive Growth Ecosystem}

Once established, the inclusive growth ecosystem needs continual monitoring and adapting. Even the best strategies and plans encounter unexpected events and circumstances not anticipated when originally formulated. That is why effective strategy implementation requires companies to conduct monthly or quarterly strategy review meetings (Kaplan-Norton (2008)) to review recent developments, re-allocate resources, and make tactical decisions. The explicit metrics on the ecosystem and individual player balanced scorecards provide the feedback on the strategy to all ecosystem participants at periodic strategy review meetings. These meetings are not intended to assign blame for shortfalls. The meetings promote learning and cooperation by having all the participants reach a consensus about the root causes of shortfalls and the near-term actions that can address problems and respond to the changes affecting the ecosystem's performance.

The catalyst continues to add value to the ecosystem by scheduling the strategy review meeting, the logistics and agenda, assembling the data to be shared among all participants in advance, and conducting the actual meeting. After the meeting, the catalyst documents and distributes the decisions agreed upon, shares them with the participants, and follows up with the people who have been assigned to implement the near-term decisions and actions.

Annually, the catalyst schedules a longer, perhaps two day, strategy review meeting to assess and adapt the entire ecosystem strategy to the knowledge gained during the prior year along with updated forecasts about future events and conditions. The participants may decide to update the strategy maps, metrics, and initiatives in light of recent and anticipated future developments. This enables the ecosystem to be agile and adaptive to changes in its operating environment, including making strategic decisions about expansion, new financing, financial distributions, and new entities to invite into the inclusive growth ecosystem.

\section{Conclusion}

Improving corporate engagement with society, as advocated in the Business Roundtable's 2019 statement, should not be viewed as a zero-sum proposition where attention to new stakeholders detracts from shareholder value. By committing to an intelligent redesign of supply chains for products, services, and talent, companies can achieve substantial growth in revenues and profits while improving the environment and offering hope for those left behind during the rapid global growth of the past 75 
years. But to achieve these ambitious goals requires more than signing up for noble and inspiring commitments. Companies must implement internal reforms in target setting and incentives for line executives, and work with a catalyst to help them form long-lasting sustainable and accountable relationship with multiple new actors in the communities where they work. 


\section{Appendix}

Sustainable and poverty-alleviating agricultural supply chains are elusive

A headline in the June 5, 2019 Washington Post: “Cocoa's child laborers: Mars, Nestlé and Hershey pledged nearly two decades ago to stop using cocoa harvested by children. Yet much of the chocolate you buy still starts with child labor." This failure was not for lack of trying. US and European companies had poured massive resources into well-intentioned sustainability programs in two countries, Ivory Coast and Ghana, that produced $60 \%$ of the world's cocoa supply. To improve yields, the programs trained farmers and provided them with free seedlings to replace their very old trees. The goal was to be able to certify that cocoa production did not use child labor and was not grown on deforested land.

These noble programs, however, failed to address systemic problems. Even with dramatically increased yields, farmers growing trees on only one hectare of land had no pathway out of extreme poverty. Furthermore, governments had set farmgate prices below already low and fluctuating commodity market prices. This discouraged the investment needed to expand and intensify on-farm production or to improve post-harvest quality and efficiency. The result: aging farmers, whose own children had left the farm to seek employment in urban centers, used the children of even poorer Africans and continued to slash and burn forested land to expand their farms.

The systemic issues in cocoa may quickly turn from a reputational and regulatory challenge for companies to an existential problem. Extremely poor farmers continue to collect cocoa-at whatever price-in order to survive. But if there is no investment in a new ecosystem that attracts younger entrepreneurs and mitigates environmental challenges, where will tomorrow's cocoa come from? 


\section{References}

Fuller, J.B., Kerr, W.R., Raman, M., and Maruyama, D. The Golden Triangle: Back in Business (A). Harvard Business School Case 818-089, January 2019.

Kaplan, R.S., and Norton, D.P. (2008). Execution Premium: Linking Strategy to Operations for Competitive Advantage. Harvard Business Press: Chapter 8.

Kaplan, R.S., Norton, D.P. and Rugelsjoen, B. (2010). Managing Alliances with the Balanced Scorecard. Harvard Business Review 88, nos. 1/2 (January-February): 114-120.

Kaplan, R.S., Serafeim, G., and Tugendhat, E. (2018). Inclusive Growth: Profitable Strategies for Tackling Poverty and Inequality. Harvard Business Review 96, no. 1 (January-February): 127-133.

Rangan, K., Chase, L., and Karim, S. (2015). The truth about CSR. Harvard Business Review 93, nos. 1/2 (January-February): 40-49.

Simons, R. (2005). Designing High-Performance Jobs. Harvard Business Review 83, nos. 7/8 (July-August) 
The small-farmer based cacao system, when mapped on a value chain, reveals inefficiencies that negatively impact farmgate prices, investment, and quality

\section{Underutilized Enablers}

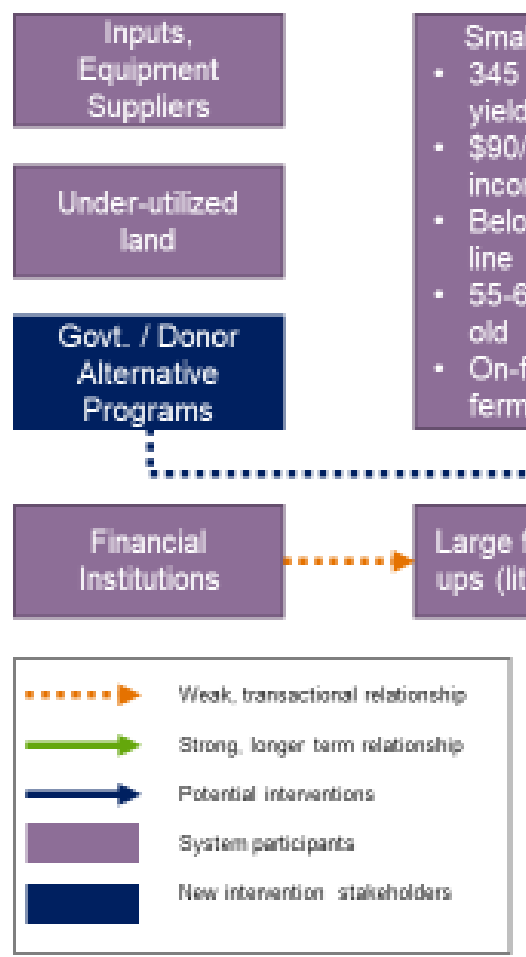

ondarn

\section{Production}

Consolidators

Tier 3 Consolidators

igoimonth $\mathrm{H} / \mathrm{A}$ income

inew poverty

On-farm

fermentation

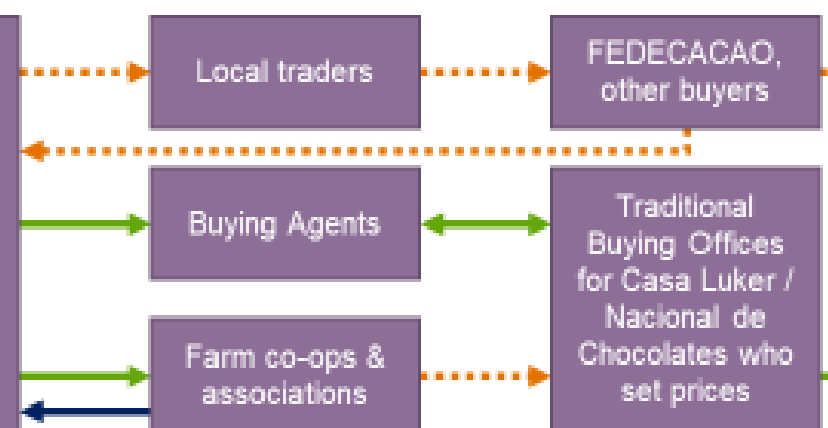

Tier 2 Aggregators

Tier 1 Suppliers

\section{End Buyers}

\section{Suppliers}
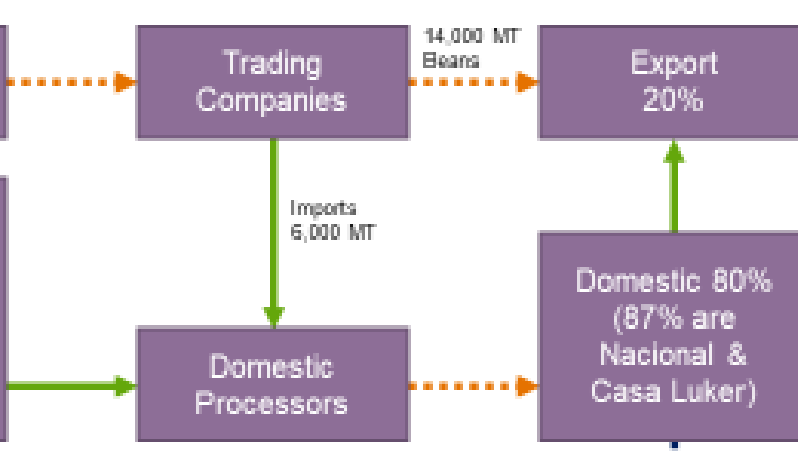

\section{Sustainability Programs}

\section{Why the System is not Working Well for Anyone}

1. Market to Farm Connections: A duopoly controls the domestic market, sets farm prices monthly and dominates weak aggregation systems

2. Production Structure: Almost entirely small-scale farms, although a number of large farms are emerging

3. System Economics \& Profitability: Farm gate price is $\$ 1,980 / M T$ even for fine flavor cacao leaving margins negative to slightly positive at average yields and coca remains a major source of income

4. Underutilized Enablers \& Sustainability: Massive USAID assistance programs have contributed to more post-harvest processing but little systemic change or improvement in farmer incomes or the cocoa system at large 


\section{Inclusive Growth Outcomes}

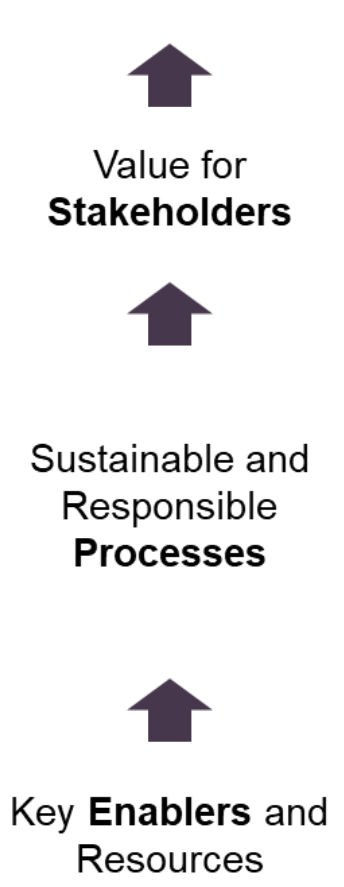

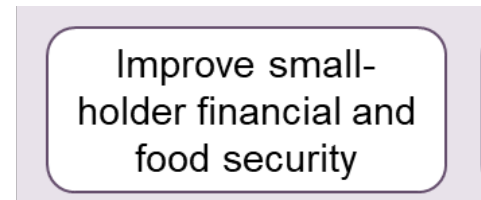
Grow a stable, higher- margin, and productive cocoa market

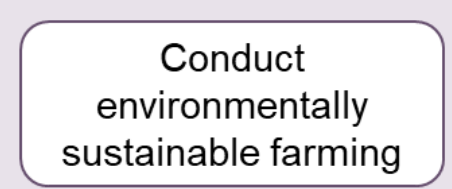

\begin{tabular}{|c|c|c|c|c|c|}
\hline $\begin{array}{l}\text { Farmers: } \\
\text { "Better yield } \\
\text { and higher } \\
\text { crop prices" }\end{array}$ & $\begin{array}{c}\text { Aggregators: } \\
\text { "More consistent } \\
\text { production } \\
\text { capability" }\end{array}$ & $\begin{array}{l}\text { Input Suppliers: } \\
\text { "Effective, loyal } \\
\text { use of our } \\
\text { products" }\end{array}$ & $\begin{array}{c}\text { Financiers: } \\
\text { "Positive return, } \\
\text { secured lending } \\
\text { opportunities" }\end{array}$ & & $\begin{array}{l}\text { ff-takers: } \\
\text { iable, high- } \\
\text {, sustainable } \\
\text { ıct sourcing" }\end{array}$ \\
\hline The Land & & Farm Investment & \multicolumn{3}{|c|}{ Farm Investment } \\
\hline $\begin{array}{c}\text { Protect and } \\
\text { improve quality of } \\
\text { the soil }\end{array}$ & & $\begin{array}{c}\text { Efficient access to } \\
\text { farm inputs through } \\
\text { aggregators }\end{array}$ & \multicolumn{3}{|c|}{$\begin{array}{l}\text { Form cooperatives to } \\
\text { realize economies of scale } \\
\text { and aggregate locally }\end{array}$} \\
\hline $\begin{array}{l}\text { Clarify title to the } \\
\text { land }\end{array}$ & & $\begin{array}{l}\text { Provide farmers } \\
\text { access to capital }\end{array}$ & & \multicolumn{2}{|c|}{$\begin{array}{l}\text { Invest in farmer skill } \\
\text { building }\end{array}$} \\
\hline $\begin{array}{c}\text { Invest in basic } \\
\text { infrastructure and } \\
\text { community security }\end{array}$ & $\begin{array}{l}\text { Build trusted } \\
\text { partnerships across } \\
\text { ecosystem actors }\end{array}$ & $\begin{array}{r}\text { Sustain ac } \\
\text { commitm } \\
\text { through quic }\end{array}$ & \multicolumn{2}{|c|}{$\begin{array}{l}\text { Secure new } \\
\text { capital to enable } \\
\text { the ecosystem }\end{array}$} & $\begin{array}{l}\text { Collect and } \\
\text { digitize } \\
\text { ecosystem data }\end{array}$ \\
\hline
\end{tabular}


The catalyst helps develop linked strategy maps for the inclusive growth ecosystem

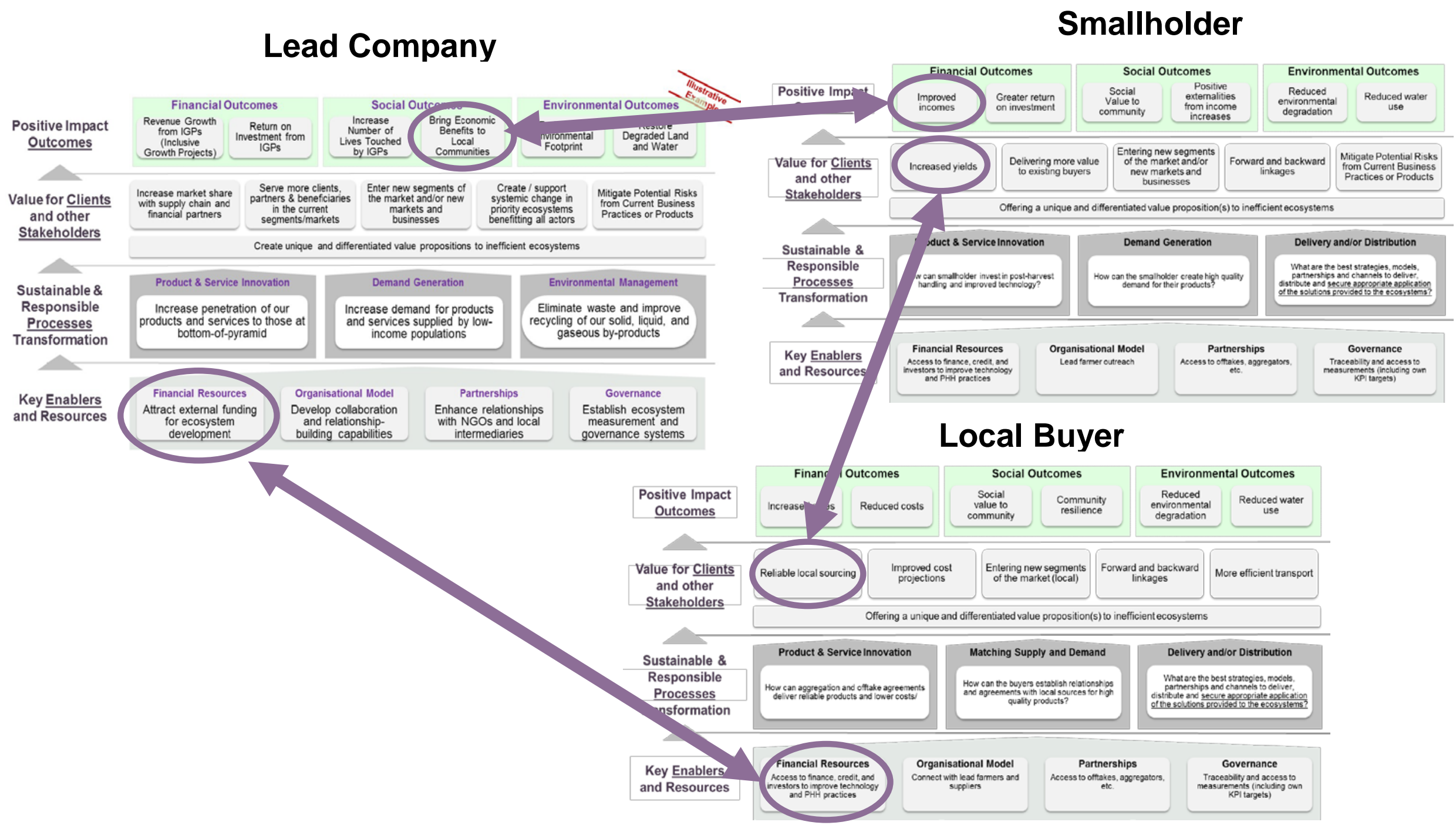

